\title{
Interspecific Amplexus of a Six-lined Treefrog, Polypedates taeniatus (Boulenger 1908), and a Chunam Treefrog, $P$. maculatus (Gray 1830) (Anura: Rhacophoridae), in Chitwan National Park, Nepal
}

\author{
Santosh Bhattarai ${ }^{1}$, Pabitra Gotame ${ }^{1}$, Chiranjibi Prasad Pokheral ${ }^{1}$, Babu Ram Lamichhane ${ }^{1}$, \\ Ram Chandra Kandel, ${ }^{2}$ and Naresh Subedi ${ }^{3}$ \\ ${ }^{1}$ National Trust for Nature Conservation, Biodiversity Conservation Center, Sauraha, Chitwan-44204, Nepal (santosh.bhattarai@hotmail.com) \\ ${ }^{2}$ Chitwan National Park, Kasara, Nepal \\ ${ }^{3}$ National Trust for Nature Conservation, Khumaltar, Lalitpur, Nepal
}

$S^{n}$ uccessful reproduction in anurans is facilitated by communication cues such as visual displays or audible calls. Such communication strategies should reflect species-specific aspects of morphology, courtship posture, chemical signals, vocalization and a degree of sexual dimorphism (Bowcock et al. 2008). However, such cues are not always effective, leading some anuran males to attempt to mate with females or males of other species, and even with inanimate objects (e.g., Banta 1914; Storm 1960; Pearl et al. 2005; Mollov et al. 2010; Simovik et al. 2014). Incidents of interspecific and multiple amplexus (several males attempting to mate with the same female) may be most common among explosive breeders due to the short breeding period and high numbers of competing males at a breeding site (Wells 2007; Lomarrdo et al. 2016). Cases of interspecific and multiple amplexus have been reported in several amphibians (e.g., Ayres 2008; Vivek et al. 2014; Shahrudin 2016), but have not been reported from Nepal. Herein we document interspecific amplexus between Polypedates taeniatus and P. maculatus.

The Six-lined Treefrog, Polypedates taeniatus (Boulenger 1908), is a small, slender bush frog typically with six longitudinal black dorsal stripes (Schleich and Kastle 2002). In Chitwan National Park, calling males aggregate in open grasslands during monsoons (Bhattarai et al. 2017), where they occur sympatrically with the larger Chunam Treefrog, Polypadates maculatus (Gray 1830).

During a herpetological survey at $2145 \mathrm{~h}$ on 1 August 2017, we observed a male $P$. taeniatus in amplexus with a female P. maculatus (Fig. 1) on Signal Grass (Brachiria sp.) at a height of $1.5 \mathrm{~m}$ above the ground at the National Trust for Nature Conservation-Biodiversity Conservation Center
(NTNC-BCC) office camp in Suaraha, Chitwan National Park (273 $\left.34^{\prime} 35.39^{\prime \prime} \mathrm{N}, 8^{\circ} 29^{\prime} 48.55^{\prime \prime} \mathrm{E}\right)$. Both species are abundant at the NTNC-BCC during the monsoon season. We observed the pair in amplexus for more than $15 \mathrm{~min}$ and deposited a photographic voucher [ZRC(IMG) 1.122] at the Lee Kong Chian Natural History Museum, National University of Singapore. We did not observe any other incidents of interspecific amplexus during our survey in JulyAugust 2017.

Because $P$. taeniatus and $P$. maculatus are closely related species in the family Rhacophoridae, hybridization might be possible. We were unable to determine if the female depos-

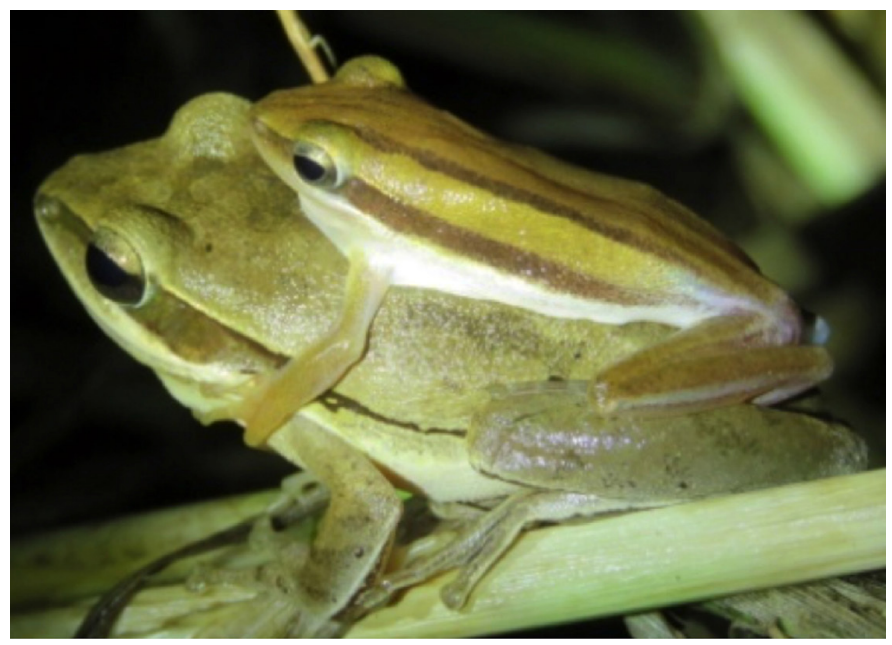

Fig. 1. Interspecific amplexus between a male Six-lined Treefrog (Polypedates taeniatus; top) and a female Chunam Treefrog (P. maculatus; bottom) in Chitwan National Park, Nepal [ZRC(IMG) 1.122]. Photograph by Santosh Bhattarai. 
ited eggs. Sympatry in pairs of Polypedates species is common, but we are unaware of any molecular studies that have documented introgression. We suggest detailed reproductive and molecular studies in order to document potential genetic similarity of these phylogenetically close species.

\section{Acknowledgements}

We thank Dip Prasad Chaudhary, Wildlife Technician, National Trust for Nature Conservation-Biodiversity Conservation Center (NTNC-BCC), Sauraha Chitwan, for help during the survey. We also thank Mark O'Shea and George Zug for comments that improved the quality of the manuscript.

\section{Literature Cited}

Ayres, C. 2008. Multiple amplexus in the Iberian Brown Frog Rana iberica. NorthWestern Journal of Zoology 4: 327-330.

Banta, A.M. 1914. Sex recognition and the mating behavior of the Wood Frog, Rana sylvatica. Biological Bulletin 26: 171-183.

Bhattarai, S., C.P. Pokheral, B.R. Lamichhane, and N. Subedi. 2017. Herpetofauna of a Ramsar Site: Beeshazar and Associated Lakes, Chitwan National Park, Nepal. Reptiles \& Amphibians 24: 17-29.
Bowcock, H., G.P. Brown, and R. Shine. 2008. Sexual communication in Cane Toads, Chaunus marinus: What cues influence the duration of amplexus? Animal Behaviour 75: 1571-1579.

Lombardo, I., S. Carreira, and R. Maneyro. 2016. Hypsiboas pulchellus (Montevideo Treefrog). Multiple amplexus. Herpetological Review 47: 111.

Mollov, I.A. 2010. Cases of abnormal amplexus in anurans (Amphibia: Anura) from Bulgaria and Greece. Biharean Biologist 4: 121-125.

Pearl, C.A., M.P. Hayes, R. Haycock, J.D. Engler, and J. Bowerman. 2005. Observations of interspecific amplexus between western North American ranid frogs and the introduced American Bullfrog (Rana catesbeiana) and an hypothesis concerning breeding interference. The American Midland Naturalist 154: 126-134.

Schleich, S.H. and W. Kästle (eds.). 2002. Amphibians and Reptiles of Nepal: Biology, Systematics, Field Guide. A.R.G. Gantner Verlag KG, Ruggell, Liechtenstein.

Shahrudin, S. 2016. Interspecific amplexus between male Rhacophorus prominanus and female Polypedates leucomystax from peninsular Malaysia. Herpetological Bulletin 135: 30-31.

Simovi , A., L. Anderson, M. An elkovi, S. Gvozdenovi, and S. Đor evi . 2014. Unusual amplexuses between anurans and caudates. Herpetology Notes 7: 25-29.

Storm, R.M. 1960. Notes on the breeding biology of the Red-legged Frog (Rana aurora aurora). Herpetologica 16: 251-259.

Vivek, S., M. Dinesh, K.R. Kumar, Y. Divaker, and K.K. Sharma. 2014. Interspecies mating interactions between Duttaphrynus stomaticus (Marbled Toad) and Sphaerotheca breviceps (Indian Burrowing Frog) at the Central Aravalli Foothills, Rajasthan, India. Herpetology Notes 7: 139-140.

Wells, K.D. 2007. The Ecology and Behavior of Amphibians. The University of Chicago Press, Chicago, Illinois. 